\title{
Teori Belajar Behavioristik Dalam Pembelajaran Matematika Sekolah Dasar Berdasarkan Kurikulum 2013
}

\author{
Ety Mukhlesi Yeni ${ }^{1}$; Riandi Marisa ${ }^{2}$ \\ ${ }^{12}$ Dosen Program Studi Pendidikan Guru Sekolah Dasar FKIP Universitas Almuslim \\ Email: emyitsme@gmail.com, riandy_marisa@yahoo.co.id
}

Diterima 10 Juni 2021/Disetujui 24 Juni 2021

\begin{abstract}
ABSTRAK
Kajian pustaka ini bertujuan untuk menjelaskan lebih mendalam tentang teori belajar behavioristik dalam pembelajaran matematika di sekolah dasar berdasarkan kurikulum 2013. Teori behavioristik menjadi salah satu landasan teori belajar yang digunakan dalam merancang perangkat pembelajaran. Siswa dalam pembelajaran matematika menggunakan teori behavioristik sama halnya dengan membentuk pola pikir siswa melalui pemberian stimulus respon. Sesuai karakteristik siswa sekolah dasar yang membutuhkan stimulus untuk memahami konsep-konsep materi matematika. Berdasarkan kurikulum 2013 yang memiliki tujuan bahwa pembelajaran harus bermakna bagi siswa, yaitu siswa dapat menerapkan ilmu pengetahuan yang diperoleh dalam kehidupan sehari-hari. Maka, guru diharapkan mampu memahami pengetahuan awal, serta sikap dan keterampilan siswa untuk menentukan tujuan pembelajaran yang tertuang dalam rencana pelaksanaan pembelajaran. Lalu, merancang evaluasi formatif yang berguna sebagai umpan balik dari proses pembelajaran yang telah dilaksanakan serta memberikan motivasi dan semangat baru kepada peserta didik dalam rangka mewujudkan perubahan perilaku yang diinginkan.
\end{abstract}

Kata kunci: teori behavioristik, pembelajaran matematika, kurikulum 2013

\section{PENDAHULUAN}

Manusia sejak dilahirkan terus belajar mengenal hal-hal baru dalam hidupnya, belajar sampai memahami apa yang dipelajari guna merubah perilaku dan kemampuannya, serta belajar sampai mampu bertahan dan melanjutkan kehidupannya. Belajar tidak mengenal usia, seorang manusia terus belajar sejak bayi sampai tua, sehingga kebutuhan belajar menjadi kebutuhan primer bagi manusia. Hal ini disebabkan manusia terlahir dengan tidak mengetahui apa-apa dan hanya dibekali potensi jasmaniah dan rohaniah (QS. An-Nahl:78), sehingga manusia mampu mengaktualisasikan potensi yang dimilikinya secara maksimal melalui belajar. Maka, belajar dilakukan manusia secara terusmenerus, sepanjang hayat (life long education), di sekolah maupun di luar sekolah, secara formal atau non formal, dibimbing ataupun tidak (Rusuli, 2014).

Belajar adalah proses memperoleh pengetahuan dan keterampilan (Gray, dkk., 2012). Suyono., Hariyato (dalam Rachmawati, dkk., 2015:36), juga menyampaikan bahwa belajar merupakan aktivitas atau proses untuk memperoleh pengetahuan, meningkatkan keterampilan, memperbaiki perilaku, sikap dan mengokohkan kepribadian. Kepribadian yang kokoh akan menguatkan jati dirinya sebagai orang yang berilmu, namun diharapkan rendah hati dan tidak sombong. Oleh karena itu, kualitas dari hasil proses perkembangan manusia bergantung pada apa dan bagaimana manusia tersebut belajar. Hal ini dikarenakan manusia melakukan perubahan kualitatif individu sehingga tingkah lakunya berkembang melalui belajar (Rusuli, 2014). Adapun tinggi rendahnya kualitas perkembangan manusia, akan menentukan masa depan peradaban manusia tersebut (Rusuli, 2014). Sehingga, jika kemampuan belajar umat manusia hilang, maka tidak akan ada peradaban yang bisa diwariskan kepada anak cucu.

Menurut Berkson., Wettersten (dalam Rusuli, 2014), menyatakan bahwa hal ideal yang seharusnya terjadi dalam proses belajar tidak hanya berupa pemindahan (transfer), tetapi pengubahan (transformation); baik pengetahuan, keterampilan, maupun nilai. Maka, belajar harus menyentuh tiga aspek, yaitu kognitif, psikomotorik dan afektif. Sehingga, belajar tidak hanya sebagai pemenuhan kepuasan intelektual belaka, tetapi berfungsi sebagai transformasi terhadap tingkah laku individu. 
Banyak teori belajar yang telah dikemukakan para ahli pendidikan dan psikologi. Teori-teori tersebut mengakomodir tujuan belajar yang diharapkan tercapai oleh pendidik. Ada beberapa teori belajar dan pembelajaran dalam dunia pendidikan, dan memiliki aspek penekanan yang berbeda dalam proses implikasinya. Teori-teori tersebut adalah teori behavioristik, teori belajar kognitif, teori konstruktivisme, teori humanistik dan teori belajar sosial kultural (Rachmawati, dkk., 2015:54).

Adapun pembelajaran di kelas terlihat bahwa guru mencoba berbagai teori belajar yang dipahami dan menerapkannya dalam proses belajar mengajar di kelas. Oleh karena itu, guru harus mampu mengakomodir perbedaan intelektual dan perkembangan siswa di kelas. Hal ini dikarenakan setiap teori memiliki implikasi yang berbeda dalam penerapannya di kelas. Teori behavioristik merupakan salah satu teori belajar yang masih menjadi rujukan bagi guru dalam melaksanakan pembelajaran di kelas. Teori behavioristik menekankan pada perubahan tingkah laku peserta didik yang didapatkan dari pengalaman belajar. Teori ini akan berhasil jika guru mampu mengkondisikan siswa dengan aturan yang sudah disepakati bersama sebelum pembelajaran dilaksanakan. Proses pembelajaran menuntut guru untuk mampu memberikan stimulus yang baik agar siswa dapat merespon dengan baik saat pembelajaran berlangsung. Guru menjadi sumber belajar utama yang dilengkapi media pembelajaran supaya siswa termotivasi belajar, khususnya dalam pembelajaran matematika.

\section{PEMBAHASAN}

\section{Teori Belajar Behavioristik}

Teori belajar behavioristik adalah teori yang dicetuskan oleh Gage dan Berliner tentang perubahan tingkah laku sebagai hasil dari pengalaman. Teori ini berkembang menjadi aliran psikologi belajar yang berpengaruh terhadap arah pengembangan teori dan praktik pendidikan yang dikenal sebagai aliran behavioristik, yang menekankan terbentuknya perilaku sebagai hasil belajar (Rachmawati, dkk., 2015:55). Lalu, Amsari., Mudjiran (2018), menyatakan teori belajar behaviouristik adalah teori belajar yang menekankan pada tingkah laku manusia, memandang individu sebagai makhluk reaktif yang memberi respon terhadap lingkungan. Sehingga, pengalaman dan pemeliharaan membentuk perilaku.

Salah satu tokoh pengusung teori belajar behavioristik adalah Edward Lee Thorndike (1874-1949). Menurut Thorndike, belajar merupakan peristiwa terbentuknya asosiasi-asosiasi antara peristiwaperistiwa yang disebut stimulus dan respon. Stimulus adalah perubahan dari lingkungan eksternal yang menjadi tanda untuk mengaktifkan organisme dalam bereaksi. Sedangkan, respon adalah sembarang tingkah laku yang dimunculkan karena adanya perangsang (Burhanuddin, 2008).

Thorndike (dalam Moreno, 2010), mengemukakan bahwa terjadinya asosiasi antara stimulus dan respon mengikuti hukum-hukum, berikut: 1) hukum kesiapan (law of readiness), yaitu semakin siap organisme memperoleh perubahan tingkah laku, maka pelaksanaan tingkah laku tersebut akan menimbulkan kepuasan individu sehingga asosiasi cenderung diperkuat; 2) hukum latihan (law of exercise), yaitu semakin sering tingkah laku diulang/dilatih (digunakan), maka asosiasi tersebut semakin kuat; 3) hukum akibat (law of effect), yaitu hubungan stimulus respon cenderung diperkuat jika akibatnya menyenangkan dan diperlemah jika akibatnya tidak memuaskan.

Berdasarkan perkembangannya sebagai aliran psikologi belajar, behaviorisme memandang individu dari sisi fenomena jasmaniah dan mengabaikan aspek mental, seperti kecerdasan, bakat, minat dan perasaan individu dalam belajar (Andriyani, 2015). Teori ini tidak memperhatikan bahwa manusia lahir memiliki potensi dalam dirinya, tetapi teori belajar ini menekankan pada perlunya tingkah laku (behavior) yang dapat diamati. Menurut aliran behavioristik, belajar adalah pembentukan asosiasi antara kesan yang ditangkap panca indera dengan kecenderungan bertindak atau hubungan antara 
stimulus dan respons (S-R). Sehingga, teori ini dinamakan teori Stimulus Respons. Belajar adalah upaya membentuk hubungan stimulus dan respon sebanyak-banyaknya (Sanjaya, 2013:237).

Pengertian belajar menurut pandangan teori behavioristik adalah perubahan tingkah laku dari adanya interaksi antara stimulus dan respon. Seseorang dianggap telah belajar jika telah menunjukkan perubahan tingkah laku (Rachmawati, dkk., 2015:55). Menurut teori ini yang terpenting adalah input berupa stimulus dan output berupa respon. Sedangkan apa yang terjadi diantara stimulus dan respon dianggap tidak dapat diperhatikan, karena tidak dapat diamati dan diukur. Adapun yang dapat diamati adalah stimulus dan respon, sehingga apa yang diberikan guru berupa stimulus dan apa yang dihasilkan siswa berupa respon, dapat diamati dan diukur. Teori ini mengutamakan pengukuran sebagai hal penting untuk melihat terjadi tidaknya perubahan tingkah laku tersebut.

Faktor lain yang dianggap penting dari teori behavioristik adalah faktor penguatan (reinforcement). Penguatan adalah apa yang dapat memperkuat timbulnya respon. Sehingga menjadi bagian dari pengertian lanjutan atas teori belajar behavioristik, yaitu belajar adalah kontrol instrumental yang berasal dari lingkungan. Belajar tidaknya seseorang bergantung pada faktor kondisional lingkungan (Siregar, dkk., 2010:25). Maka, disimpulkan bahwa perubahan tingkah laku dibentuk sesuai keinginan lingkungan, karena individu merespon sesuai dengan stimulus yang diberikan. Selain itu, respon yang diberikan akan baik, jika seseorang siap menerima stimulus, sehingga menimbulkan kepuasan bagi individu tersebut. Untuk mendapatkan hasil belajar yang baik berupa perubahan tingkah laku, maka pemberian stimulus dilakukan berulang kali, agar respon yang diberikan semakin baik.

\section{Kelebihan dan Kekurangan Teori Belajar Behavioristik}

Setiap teori memiliki kelebihan dan kekurangan, tidak selalu tampak baiknya saja namun ada efek buruknya juga saat diimplementasikan dalam proses pembelajaran di kelas. Berikut beberapa kelebihan dan kekurangan dari teori behavioristik (Rachmawati, dkk., 2015:60).

Tabel 1. Kelebihan dan Kekurangan Teori Behavioristik

\begin{tabular}{|c|c|}
\hline Kelebihan & Kekurangan \\
\hline $\begin{array}{l}\text { Teori ini dapat mengganti stimulus yang satu } \\
\text { dengan stimulus lainnya dan seterusnya sampai } \\
\text { respons yang diinginkan muncul. }\end{array}$ & $\begin{array}{l}\text { Cenderung mengarahkan siswa untuk berpikir } \\
\text { linier, konvergen, tidak kreatif, tidak produktif } \\
\text { dan menjadikan siswa sebagai individu pasif. }\end{array}$ \\
\hline $\begin{array}{l}\text { Teori ini cocok untuk memperoleh kemampuan } \\
\text { yang membutuhkan praktek dan pembiasaan } \\
\text { berupa kecepatan, spontanitas dan daya tahan. }\end{array}$ & $\begin{array}{l}\text { Pembelajaran siswa berpusat pada guru dan } \\
\text { bersifat mekanistik dan hanya berorientasi } \\
\text { pada hasil yang diamati dan diukur. }\end{array}$ \\
\hline $\begin{array}{l}\text { Teori ini cocok digunakan untuk melatih siswa } \\
\text { yang masih membutuhkan peran orang dewasa, } \\
\text { suka mengulangi dan dibiasakan, suka meniru dan } \\
\text { senang dengan bentuk penghargan langsung. }\end{array}$ & $\begin{array}{l}\text { Penerapan metode yang salah dalam } \\
\text { pembelajaran menjadikan proses pembelajaran } \\
\text { tidak menyenangkan bagi siswa. }\end{array}$ \\
\hline
\end{tabular}

\section{Perkembangan Teori Behavioristik dalam Pembelajaran Matematika}

Teori behavioristik yang memandang pembelajaran sebagai perubahan dalam tingkat, frekuensi kemunculan atau bentuk perilaku atau respon yang terjadi sebagai sebuah fungsi dari faktor-faktor lingkungan. Cara belajar yang khas yang ditunjukkannya adalah trial dan error (Schunk, 2012:31). Behavioristik menganjurkan dalam pembelajaran harus ada tujuan tertentu yang dinyatakan dalam rancangan pembelajaran. Siswa harus melakukan sesuatu sebagai hasil dari pembelajaran. Spesifikasi tujuan perilaku adalah langkah pertama dalam kurikulum dan perencanaan kelas. Setelah tujuan ditetapkan, program didesain agar pelajar mendapatkan perilaku yang diinginkan (Eisenberg, 1975).

Guru yang menggunakan paradigma behaviorisme akan menyusun bahan pelajaran dalam bentuk yang sudah siap, sehingga tujuan pembelajaran yang harus dikuasai siswa disampaikan secara utuh. Guru 
tidak banyak memberi ceramah, tetapi instruksi singkat yang diikuti contoh, baik dilakukan sendiri maupun melalui simulasi. Bahan pelajaran disusun secara hierarki dari yang sederhana sampai pada yang kompleks. Sedangkan, evaluasi atau penilaian didasari atas perilaku yang tampak.

Kritik terhadap behavioristik adalah pembelajaran siswa yang berpusat pada guru, bersifat mekanistik dan hanya berorientasi pada hasil yang dapat diamati dan diukur. Namun, tidak setiap mata pelajaran memakai metode ini, sehingga kejelian dan kepekaan guru pada situasi dan kondisi belajar sangat penting untuk menerapkan kondisi behavioristik. Metode behavioristik sangat cocok untuk perolehan kemampaun yang membuthkan praktek dan pembiasaan yang mengandung unsur seperti kecepatan, spontanitas, kelenturan, reflek, daya tahan dan sebagainya.

Dari penjelasan sederhana tentang teori behavioristik dalam pembelajaran secara umum, penulis memaparkan bagaimana perannya terhadap pembelajaran matematika, sehingga adanya pengaruh baik antara konsep behavioristik dengan pembelajaran matematika. Adapun karakteristik matematika secara umum menurut Susanto., Agus (2012), adalah: 1) memiliki objek kajian abstrak, 2) bertumpu pada kesepakatan, 3) berpola pikir deduktif, 4) memiliki simbol yang kosong dari arti, 5) memperhatikan semesta pembicaraan, dan 6) konsisten dalam sistemnya. Oleh karena itu, pembelajaran matematika adalah proses belajar bagi siswa untuk mengembangkan potensi berpikir deduktif yaitu memecahkan masalah dimulai dari hal-hal umum (defenisi) ke bentuk khusus (permasalahan nyata). Hal ini sesuai dengan tujuan pembelajaran matematika di sekolah yaitu melatih siswa mengembangkan pola pikir untuk menyelesaikan permasalahan yang ditemui dalam kehidupan.

Guru hendaknya dapat memanfaatkan lingkungan sebagai tempat masalah yang menarik digali oleh siswa menggunakan ide matematika. Supaya matematika lebih bermakna, maka pembelajarannya harus bersandarkan pada pemikiran bahwa siswa yang harus belajar secara menyeluruh dan terpadu. Selain itu, guru hendaknya mampu membantu siswa untuk berpikir logis, kritis, sistematis dan mampu memecahkan masalah dalam kehidupan sehari-hari, khususnya yang berkaitan dengan matematika.

Teori behavioristik adalah teori yang banyak digunakan dalam pembelajaran di sekolah, salah satunya dalam pembelajaran matematika. Melalui teori behavioristik, siswa belajar matematika dengan membentuk pola pikir melalui pemberian stimulus respon. Implikasi dari teori belajar Thordike berindikasi kepada bagaimana seorang guru menstimulus siswa untuk mengembangkan kemampuan berpikir dalam menyelesaikan permasalahannya. Sehingga, guru membentuk pola pikir siswa sesuai dengan stimulus yang diberikan. Selanjutnya, Santrock (2011) menyatakan bahwa pembelajaran matematika adalah proses interaksi antara guru dan siswa yang melibatkan pola berpikir dan mengolah logika pada lingkungan belajar yang sengaja diciptakan guru atau yang ingin dibentuk guru dengan metode agar program belajar matematika dapat tumbuh dan berkembang secara optimal.

\section{Teori Behavioristik dalam Pembelajaran Matematika Berdasarkan Kurikulum 2013}

Kurikulum 2013 merupakan suatu konstruksi kurikulum yang mengintegrasikan dua kerangka besar, yaitu kompetensi dan karakter dalam diri peserta didik. Artinya, kurikulum ini menginternalisasikan satu kesatuan kecerdasan intelektual (intellectual qoutient), kecerdasan emosioanl (emotional qoutient) dan kecerdasan spiritual (spiritual qoutient). Apalagi fenomena perkembangan pendidikan abad mutakhir menghendaki adanya sistem pendidikan integral yaitu menghendaki pendidikan melalui pembinaan peserta didik dan dilaksanakan secara seimbang antara nilai dan sikap, pengetahuan, kecerdasan, keterampilan, kemampuan komunikasi, dan kesadaran antara IPTEK (Ilmu Pengetahuan dan Teknologi) dan IMTAQ (Iman dan Taqwa) yakni meliputi IQ (Intellectual Quotient), EQ (Emotional Quotient), dan SQ (Spritiual Quotient). (Driscoll, Marcy, 2012).

Kurikulum menjadi barometer untuk mengukur tingkat keberhasilan proses pembelajaran dalam pendidikan, sehingga salah satu entitas yang sangat urgen dalam pendidikan adalah anatomi 
kurikulum itu sendiri. Beberapa kalangan menyatakan bahwa kurikulum tidak boleh didefinisikan terlalu luas dan tidak terlalu sempit, sebab semua aspek yang terkait dengan pendidikan seperti metode belajar, sasaran pembelajaran, juga termasuk dalam lingkup kurikulum. Pendidikan akan berjalan secara sistematis dan memiliki orientasi yang jelas, karena arah pendidikan selain sebagai media peningkatan penguasaan pengetahuan, kemampuan dan keterampilan, juga merupakan sarana pengembangan nilai-nilai normatif dalam rangka membentuk jati diri peserta didik. (Minarti, 2013).

Dari dua referensi tentang kurikulum, khususnya kurikulum 2013 disimpulkan bahwa kurikulum 2013 menekankan pada pengembangan kemampuan dan keterampilan serta aspek karakter dalam melakukan tugas dengan standar performansi tertentu, sehingga hasilnya dapat dirasakan siswa, berupa penguasaan terhadap seperangkat kompetensi tertentu. Dari kurikulum ini melahirkan pola pembelajaran tematik-integratif berbasis karakter dengan ruang dialogis yang sangat luas antara guru dan siswa, sehingga memberikan gerak kebebasan bagi siswa untuk mengaktualisasikan potensinya dan mengkonstruksi ilmu pengetahuan, nilai dan norma serta nilai normatif-spiritualitasnya.

Teori behavioristik yang berlandaskan pada pengembangan karakter diri (proses belajar) yang diperoleh dari lingkungan sekitar siswa selaras dengan tujuan kurikulum 2013. Kontribusi teori belajar behavioristik dalam desain pembelajaran, yaitu: 1) tujuan instruksional khusus; 2) evaluasi formatif; dan 3) umpan balik (feedback). (Yaumi, 2017).

Sebelum merancang tujuan desain pembelajaran, memahami pengetahuan awal siswa merupakan kunci utama dalam menentukan tujuan yang akan diarahkan. Tingkat pengetahuan, sikap dan keterampilan yang mana yang mana menjadi target perubahan perilaku yang diinginkan. Mendasain sasaran kinerja atau tujuan instruksional khusus menjadi faktor penentu keberhasilan belajar, karena mengandung urutan aktivitas yang membawa siswa pada titik akhir tingkat keberhasilan. Sama halnya dengan evaluasi formatif yang bertujuan untuk mengetahui sejauh mana perubahan yang terjadi dan permasalahan yang dihadapi, sehingga pembelajaran dapat diperbaiki sesuai dengan masukan yang diperoleh selama melaksanakan evaluasi formatif tersebut. Lalu, umpan balik dalam strategi pembelajaran diperlukan untuk memberikan penguatan dan motivasi serta semangat baru kepada siswa dalam rangka untuk perubahan perilaku yang diinginkan. Hal ini sejalan dengan tujuan kurikulum 2013 terutama dalam pembelajaran matematika, yaitu siswa tidak hanya belajar matematika sebagai sesuatu yang dihadapkan dengan simbol, namun menjadi bermakna dalam kehidupan siswa sebagai manusia yang bersosial dan berketuhanan yang maha esa.

\section{SIMPULAN}

Berdasarkan pembahasan dari kajian pustaka di atas dapat disimpulkan bahwa teori behavioristik masih menjadi salah satu landasan dalam pembelajaran, yang bertujuan membentuk perubahan tingkah laku individu sesuai dengan keinginan lingkungan, karena individu merespon sesuai dengan stimulus yang diberikan. Maka, diharapkan guru dalam melaksanakan pembelajaran mampu memberikan sitmulus yang baik dan tepat untuk membentuk karakter individu yang baik. Karakter yang berbudi pekerti baik, beradab sopan santun pada diri siswa merupakan salah satu hal yang dituntut untuk dihasilkan dari penerapan kurikulum 2013. Tujuan kurikulum 2013 khususnya pada pembelajaran matematika adalah siswa tidak hanya belajar matematika sebagai sesuatu yang dihadapkan dengan angka, rumus, atau simbol semata, namun menjadi hal yang bermakna dalam kehidupan siswa sebagai manusia yang bersosial dan berketuhanan yang maha esa. 


\section{REFERENSI}

Andriyani, Fera. 2015. Teori Belajar Behavioristik dan Pandangan Islam tentang Behavioristik. Url: http://ejournal.kopertais4.or.id/index.php/syaikhuna/article/download/1034/767. diakses 26 Oktober 2020.

Amsari, D., Mudjiran. 2018. Implikasi Teori Belajar E.Thorndike (Behavioristik) dalam Pembelajaran Matematika. Jurnal Basicedu Vol. 2 No. 2 Tahun 2018, Hal. 52-60.

Burhanuddin., dkk. 2008. Teori Belajar dan Pembelajaran. Yogyakarta: An-Ruzz Media.

Driscoll, Marcy, P. 2012. Psychology Foundation of Instructional Design. Reiser, Robert A. dan Dempsey, John V. Trends and Issues in Instructional Design and Technology. Third Edition. Boston: Pearson Education Inc.

Eisenberg, Theodore A. 1975. Behaviourism: The Bane Of School Mathematics. International Journal of Mathematical Education inScience and Technology. Vol. 6 No. 2, Hal. 163-171. Url: http://www.tandfonline.com/loi/tmes20. diakses 25 Oktober 2020.

Gray, Colette., dkk. 2012. Learning Theoris in Childhood. London: SAGE Publications Ltd.

Minarti, Sri. 2013. Ilmu Pendidikan: Fakta Teoritis-Normatif \& Aplikasi Normatif. Jakarta: Amzah.

Moreno, Roxane. 2010. Educational Psychology. University of New Mexico.

Rachmawati, Tutik., dkk. 2015. Teori Belajar dan Proses Pembelajaran yang Mendidik. Yogyakarta: Gava Media.

Rusuli, Izzatur. 2014. Refleksi Teori Belajar Behavioristik dalam Perspektif Islam. Jurnal Pencerahan. Vol. 8 No. 1 Juli-Desember 2014 Hal. 38-54. Url:

http://download.portalgaruda.org/article.php?article=272304\&val=6817\&title=REFLEKSI\%20TE ORI\%20BELAJAR\%20BEHAVIORISTIK\%20DALAM\%20PERSPEKTIF\%20ISLAM. diakses 26 Oktober 2020.

Sanjaya, Wina. 2013. Kurikulum dan Pembelajaran. Jakarta: Kencana.

Santrock, John. W. 2011. Educational Psychology. University of Texas at Dallas.

Schunk, Dale H. 2012. Learning Theories: an Educational Perspective. Yogyakarta: Pustaka Pelajar.

Siregar, Eveline., dkk. 2010. Teori Belajar dan Pembelajaran. Bogor: Ghalia Indonesia.

Susanto, Agus, H. 2012. Nilai Matematika dan Pendidikan Matematika dalam Pembentukan Kepribadian. Jurnal Pendidikan dan Pembelajaran, Vol. 19 No. 1 April 2012.

Wekke, Ismail Suardi. 2019. Metode Penelitian Ekonomi Syariah. Yogyakarta: Gawe Buku.

Yaumi, Muhammad. 2017. Prinsip-prinsip Desain Pembelajaran: Sesuai Kurikulum 2013. Jakarta: Kharisma Putra Utama. 